\title{
Arctic boreal plankton species in the Northwest Atlantic
}

\author{
D.G. Johns, M. Edwards, and S.D. Batten
}

\begin{abstract}
The Continuous Plankton Recorder (CPR) survey has sampled regularly in the Northwest Atlantic since the early 1960s. Over the last decade there has been a dramatic increase in the abundance of a number of arctic boreal plankton species, notably Calanus hyperboreus (Krøyer), Calanus glacialis (Jaschnov), and Ceratium arcticum, and a southerly shift of the copepod C. hyperboreus in the CPR survey. In 1998, C. hyperboreus was recorded at its farthest position south in the survey, $39^{\circ} \mathrm{N}$, off the Georges Bank shelf edge. Other studies have reported similar parallel biological responses on three trophic levels. During the late 1990s, production of Labrador Sea Water (LSW) has been at a high, a direct response to the phase of the North Atlantic Oscillation (NAO). The increase in abundance of these species, up to four standard deviations from the long-term mean, is linked to variability in the hydrography of the area and the driving climatic processes of the North Atlantic.
\end{abstract}

\begin{abstract}
Résumé : L'inventaire à l'aide d'enregistreurs de plancton en continu (CPR) se poursuit régulièrement dans le nordouest de l'Atlantique depuis le début des années 1960. Depuis dix ans, on a noté dans l'inventaire CPR une augmentation spectaculaire du nombre d'espèces planctoniques arctiques-boréales, en particulier de Calanus hyperboreus (Krøyer), de Calanus glacialis (Jaschnov) et de Ceratium arcticum, et un déplacement vers le sud du copépode C. hyperboreus. En 1998, C. hyperboreus a été recensé à son point le plus austral au cours de $1^{\prime}$ inventaire, à $39^{\circ} \mathrm{N}$, au large du bord du banc George. D'autres études ont signalé des réactions biologiques semblables dans les trois niveaux trophiques. Durant la fin des années 1990, la production d'eau de la mer du Labrador (LSW) a été maximale en réaction directe à une phase de l'oscillation nord-atlantique (NAO). L'accroissement de densité de ces espèces, de l'ordre de jusqu'à quatre écarts-types au-dessus de la moyenne à long terme, est relié à la variabilité de l'hydrographie locale et aux processus climatiques moteurs de l'Atlantique nord.
\end{abstract}

[Traduit par la Rédaction]

\section{Introduction}

Calanus glacialis (Jaschnov) and Calanus hyperboreus (Krøyer) are both large, calanoid copepods, whose biogeographical province is thought to be arctic to cold boreal (Conover 1988). The dinoflagellate Ceratium arcticum is predominantly found in colder waters throughout the Northern Hemisphere (CPR records). All three species are known to be indicative of arctic to cold boreal conditions from the Continuous Plankton Recorder (CPR) survey, and are the most abundant of the cold water plankton species identified.

The CPR survey provides a unique long-term dataset of plankton abundance in the North Atlantic and North Sea (Warner and Hays 1994). The survey has been running for almost 70 years, using "ships of opportunity" to tow the $\mathrm{CPR}$ on regular and incidental routes, sampling at a depth of $10 \mathrm{~m}$. Each sample represents $18 \mathrm{~km}$ of tow and approximately $3 \mathrm{~m}^{3}$ of filtered seawater. Over 400 taxa of plankton are routinely identified by a team of taxonomists. By consis-

Received March 9, 2001. Accepted July 13, 2001. Published on the NRC Research Press Web site at http://cjfas.nrc.ca on October 20, 2001.

$\mathrm{J} 16248$

D.G. Johns, ${ }^{1}$ M. Edwards, and S.D. Batten. Sir Alister Hardy Foundation for Ocean Science, 1 Walker Terrace, The Hoe, Plymouth PL1 3BN, United Kingdom.

${ }^{1}$ Corresponding author (e-mail: djoh@mail.pml.ac.uk). tently monitoring the plankton over a period, changes in abundance and long term trends can be distinguished. These changes can be indicative of larger-scale phenomena, such as the North Atlantic Oscillation (NAO), a large-scale alternation of atmospheric mass with centres near the Icelandic Low and the Azores High (Stein 2000). The NAO is the dominant, recurrent atmospheric phenomenon in the North Atlantic, and accounts for over one third of the total variance in sea-level pressure (Dickson and Turrell 2000). The NAO index is known to alternate between a "high" state, typified by an intense Iceland Low and strong Azores High, and a "low" state where these pressure cells are reversed. The NAO, by driving the weather patterns in the North Atlantic, is known to have an influence on the plankton community (Planque and Fromentin 1996; Edwards et al. 2001).

The Greenland, Labrador, and Sargasso Seas are all centres of the Northwest Atlantic where the formation of mode waters carries a signal of climate change to other oceanic areas (Dickson 1997). Of most interest is the formation of Labrador Sea Water (LSW), with a characteristic low temperature and salinity, which flows out from the Labrador Sea at intermediate depths (typically as low as 1500-2000 m), north into the Irminger Sea, eastward towards the Iceland Basin, and southward into the Newfoundland Basin (Sy et al. 1997). The formation of LSW occurs in the winter, when deep convection is forced by strong northwesterly winds that cool surface waters, making them denser than the underlying water (Curry and McCartney 1996). In this area, fresh water influx, mainly derived from glacial sources, exceeds evapo- 
Fig. 1. Standardized abundance of Calanus glacialis (broken line), Calanus hyperboreus (solid line), and Ceratium arcticum (line with •) from CPR samples 1962 to 1999 in the Northwest Atlantic. The gap in the graph represents a time period of no sampling in the area.

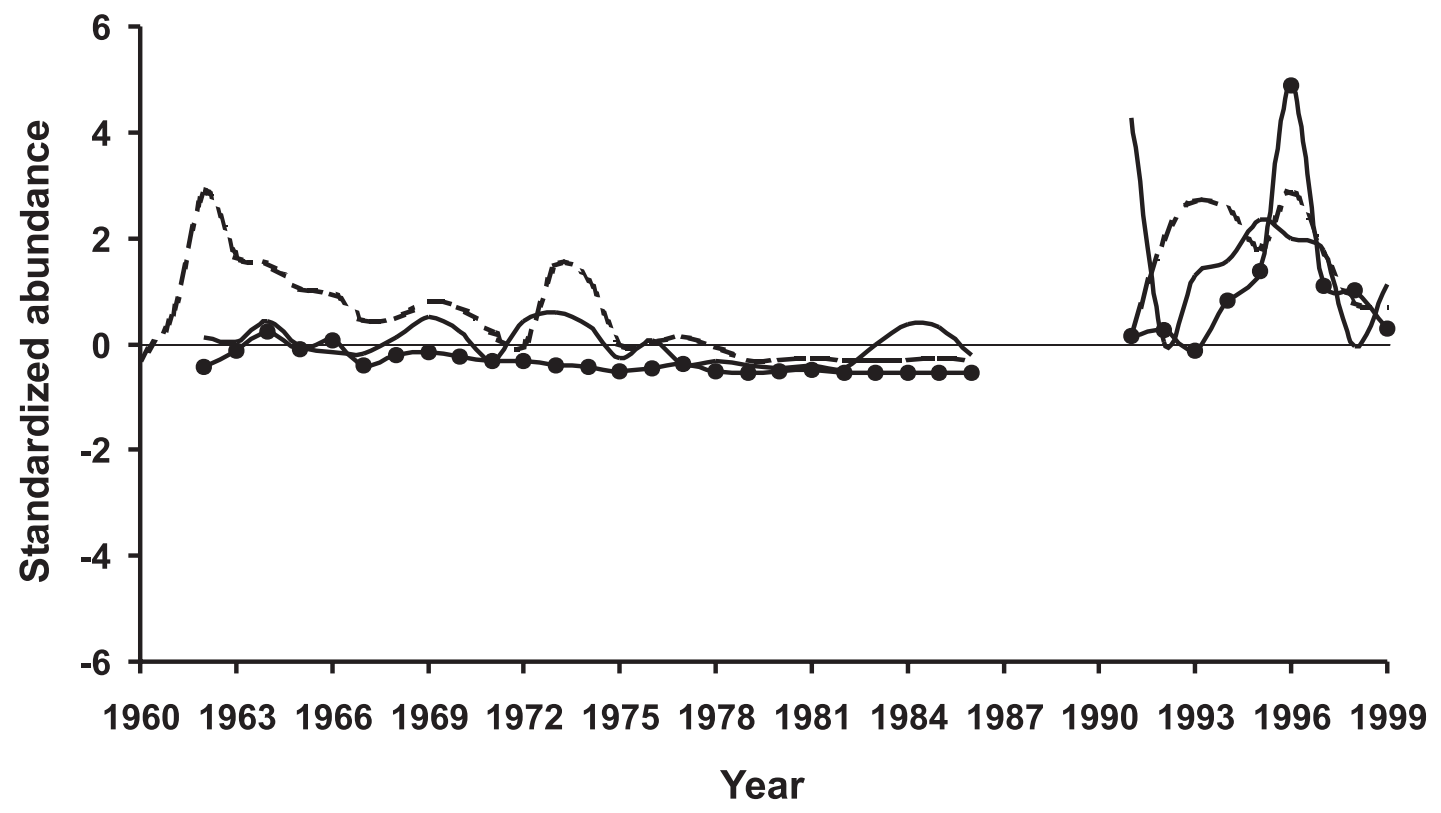

ration, and therefore the LSW is fresher than the surrounding water. By this cooling and freshening process, the LSW is created seasonally and is distinctive. It is easy to trace with its low temperature, low salinity, high oxygen content, and high anthropogenic tracer concentrations (such as chlorofluorocarbons) (Sy et al. 1997). The formation, and particularly the quantity, of the LSW is thought to be dependent on the NAO, but may also actually influence the intensity of the NAO (Dickson 1997). Therefore a change in the LSW may be indicative of a larger-scale event.

Over the past decade the abundances of the abovementioned species have increased significantly, and the range of $C$. hyperboreus has notably changed. The Labrador-Newfoundland area experienced below normal temperatures during the late 1980s to early 1990s (Prinsenberg et al. 1997), increasing the production of LSW and the strength of the Labrador Current. This study will highlight these changes and link the biogeographical variations with the dominant hydroclimatic processes in the area.

\section{Methods}

The acquisition of data from the CPR is described in full by Warner and Hays (1994). Merchant vessels on regular routes tow CPRs at monthly intervals, sampling at a depth of approximately $10 \mathrm{~m}$. Each sample represents $18 \mathrm{~km}$ of tow and approximately $3 \mathrm{~m}^{3}$ of filtered seawater. Sample data were extracted from the CPR database in the form of monthly means for the study area, $38^{\circ} \mathrm{N}$ to $56^{\circ} \mathrm{N}$ and $72^{\circ} \mathrm{W}$ to $45^{\circ} \mathrm{W}$, from 1962 until 1999 , for each species. The number of samples per year has been approximately 1500 since 1962, though unfortunately there are no records for 1987-1990. There was a peak in sampling in the late 1960s to 1970s, when over 2500 records per year were noted.

Some years were lacking data, but if there were at least seven months of data for a given year, covering the expected peak in the seasonal cycle, then the missing values were interpolated. This interpolation was carried out using a ratio estimator method (Colebrook 1975)

$$
x=y(z / q)
$$

where $x$ equals the missing months' data, y is the long-term monthly mean, $z$ is the mean of the year, and $q$ is the long-term overall mean. The results were $\log$-transformed $\left(\log _{10}+1\right)$ and then standardized to zero mean and unit variance, calculated over the period 1962 to 1986. From these data graphs of long-term abundance were plotted for each of the species (Fig. 1). The gap in the graphs represents the time period of the late 1980s when there were no tows in the area.

\section{Results and discussion}

There has been a marked increase in the number of individuals of $C$. arcticum, C. glacialis, and $C$. hyperboreus recorded during the 1990s, with exceptional peaks in C. hyperboreus abundance in 1991 (Fig. 1). In 1998 the species extended farther south than previously recorded, at $39.5^{\circ} \mathrm{N}$, south of the Georges Bank, and off the shelf break (Fig. 2). The increase in abundance for the other two species occurred later in the 1990s, 1996 for C. arcticum (an exceptional peak, over four standard deviations above the longterm mean), and in the late 1990s for C. glacialis (a gradual increase in abundance as opposed to a peak).

The results suggest a possible biological response to a change in the environmental and oceanographic conditions of the Northwest Atlantic, and this is in keeping with other reports. For example, during the early 1990s the abundance of both diatoms and dinoflagellates had increased in the area (Sameoto et al. 1996). This may represent a change in primary production, and these changes can be attributed to changes in water mass type. Nakashima (1994) has given further evidence of a change in the ecosystem of the area showing a shift in the behaviour of capelin, a small arctic smelt (Mallotus villosus). The species has extended its distri- 
Fig. 2. The most southerly extent of Calanus hyperboreus in the CPR survey in the late 1990s (slope water positions from Drinkwater et al. 1999).

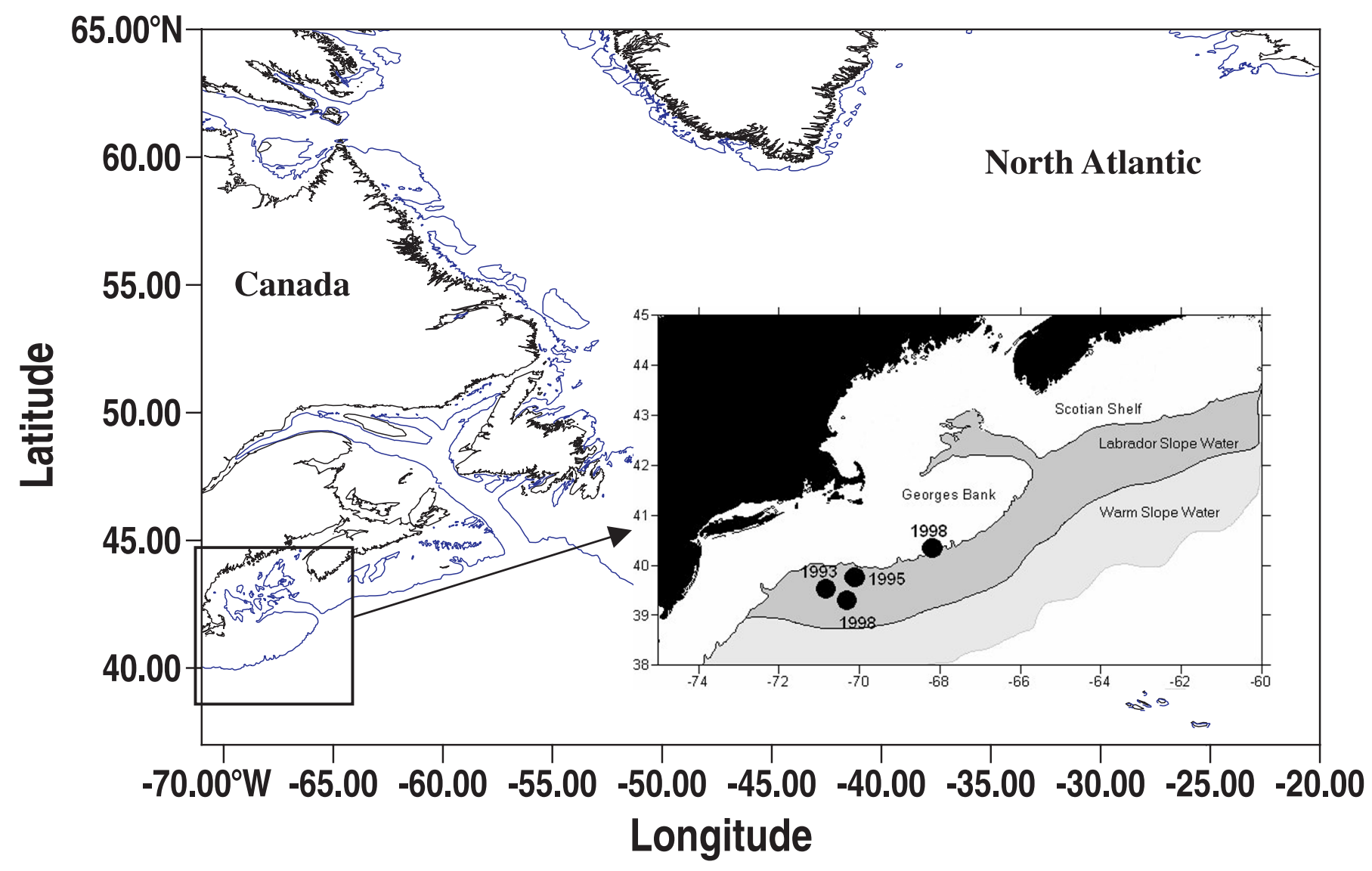

bution south onto the Flemish Cap and the Scotian Shelf and has been spawning later in the 1990s than before. It is interesting to note that the food of the capelin consists principally of large copepods, such as C. hyperboreus and C. glacialis. Since fishing pressure on the species is very low, it has been suggested that the capelin are responding to a change in the environment, particularly the colder water temperatures during the 1990s (McCartney et al. 1996). Drinkwater et al. (1999) comment that there was a rapid decline in the shark catch in the Emerald Basin and a drop in the lobster catch on the Georges Bank, both owing to the influx of colder waters. It is probable that $C$. hyperboreus, $C$. glacialis, and $C$. arcticum are all responding to these conditions.

The increase in $C$. hyperboreus as well as its appearance farther south could be explained by a greater production of LSW (Dickson 1997; Drinkwater et al. 2000; Mason et al. 2000). If so, why has there been such an increase in the LSW? The answer would seem to lie in the protracted and extreme positive phase of the NAO. During the positive NAO, cold northwesterlies increase over the Labrador Sea (Prinsenberg et al. 1997; Dickson and Turrell 2000), driving down surface temperatures (Deser 1996) and increasing the production of LSW. McCartney et al. (1996) show the close correlation between the temperature of the LSW and the phase of the NAO, and note that in the 1990s the LSW was at its coldest, freshest, and thickest (Clarke and Yashayaev 2000), corresponding closely to the peaks in C. hyperboreus abundance. This LSW has now been tracked by oceanographers, suggesting that these waters move out across the North Atlantic. Sy et al. (1997) propose that lenses of cold, less dense LSW have been identified moving farther south, close to the continental slope of the Grand Banks. This would bring colder conditions to an area formerly unfavourable for C. hyperboreus.

There appears to be a connection between the phase of the NAO and the production of LSW. But Dickson (1997) suggests that the two events are so closely linked as to be driving each other. The NAO positive phase cools more surface water to produce more LSW, and this increased production seems to feed the NAO. It is as if the whole process has a "memory," and each subsequent phase adds to the last, amplifying the intensity (Dickson 1997).

There have been similar studies on biological responses to changing conditions in the Northeast Atlantic. Reports on Calanus finmarchicus in the North Sea (Planque and Fromentin 1996) have shown how a species can react to long-term environmental changes. In the North Sea, the NAO has an effect on sea surface temperatures opposite to that in the Labrador Sea. In the North Sea the mean temperature has risen over the past decade, and this has been attributed to the positive phase in the NAO (Becker and Pauly 1996). In the late 1980 s to early 1990s the NAO index was in a prolonged extreme and positive phase (Dickson and Turrell 2000). This had detrimental effect on boreal species, 
and both $C$. finmarchicus and $C$. hyperboreus have declined significantly over the last few decades. In fact, C. hyperboreus has not been recorded in the North Sea since 1979 (Edwards et al. 2001), and more temperate species have increased in abundance.

The results presented above suggest a direct response by these species to a change in the surrounding environment (in this case one that is cooling). Parallel biological responses to increased LSW production on three trophic levels, from phytoplankton through zooplankton to fish, have been identified in similar studies in the region. So what is the cause of these colder conditions in the Northwest Atlantic? Hypotheses differ; some suggest that the positive phase of the NAO is causing an increase in LSW production (Dickson 1997). Others argue that the negative phase of the NAO, such as in 1996, causes increased southward transport of the Labrador Current (Drinkwater et al. 1999). But the general trend of the NAO in the late 1990s has been positive, so it could therefore be hypothesised that the positive phase of the NAO is causing stronger winter winds over the Labrador Sea, increasing production of LSW. This cold, fresh water is spreading out, carrying its signature farther south, and the biota of the region, along with that advected in, responds accordingly. These changes emphasise the need to maintain regular systematic monitoring programs for the Northwest Atlantic.

\section{Acknowledgements}

The CPR survey is supported by a funding consortium comprising the Intergovernmental Oceanographic Commission (IOC), United Nations Industrial Development Organization (UNIDO), the European Commission, and agencies from Canada, Denmark, The Netherlands, U.K., and U.S.A. The survey depends on the voluntary cooperation of owners, masters, and crews of merchant vessels, which tow the CPRs on regular routes. We also wish to thank the CPR survey team past and present, and Dr. R.J. Conover for his constructive comments.

\section{References}

Becker, G., and Pauly, M. 1996. Sea surface changes in the North Sea and their causes. ICES J. Mar. Sci. 53: 887-898.

Clarke, A., and Yashayaev, I.M. 2000. Changes of the water masses of the Northwest Atlantic, IGY to WOCE. Bedford Institute of Oceanography, Dartmouth, N.S., Canada (http://www.bio.gc.ca/).

Colebrook, J.M. 1975. The Continuous Plankton Recorder survey: automatic data processing methods. Bull. Mar. Ecol. 8: 123-142.
Conover, R.J. 1988. Comparative life histories in the genera Calanus and Neocalanus in high latitudes of the Northern Hemisphere. Hydrobiologia, 167/168: 127-142.

Curry, R.G., and McCartney, M.S. 1996. Labrador Sea water carries Northern climate signal south. Oceanus, 39: 24-28.

Deser, C. 1996. A century of North Atlantic data indicates interdecadal change. Oceanus, 39: 11-13.

Dickson, R. 1997. From the Labrador Sea to global change. Nature (London), 386: 649-650.

Dickson, R.R., and Turrell, W.R. 2000. The NAO: the dominant atmospheric process affecting variability in home, middle and distant waters of European salmon. In The ocean life of Atlantic salmon: environmental and biological factors influencing survival. Edited by D. Mills. Fishing News Books, London.

Drinkwater, K.F., Mountain, D.B., and Herman, A. 1999. Variability in the slope water properties off eastern North America and their effects on the adjacent shelves. ICES CM 1999/O:08.

Drinkwater, K.F., Colbourne, E., and Gilbert, D. 2000. Overview of environmental conditions in the Northwest Atlantic in 1998. NAFO Sci. Counc. Stud. 33: 39-87.

Edwards, M., Reid, P.C., and Planque, B. 2001. Long-term and regional variability of phytoplankton biomass in the Northeast Atlantic (1960-1995). ICES J. Mar. Sci. 58: 39-49.

Mason, C.S., Petrie, B., and Topliss, B.J. 2000. Satellite measurement of sea - surface temperature: an application to regional ocean climate. NAFO Sci. Counc. Stud. 32: 45-54.

McCartney, M.S., Curry, R.G., and Bezdek, H.F. 1996. North Atlantic's transformation pipeline chills and redistributes subtropical water. Oceanus, 39: 19-23.

Nakashima, B.S. 1994. The relationship between oceanographic conditions in the 1990's and changes in spawning behavior, growth and early life history of capelin (Mallotus villosus). NAFO Sci. Counc. Stud. 24: 55-68.

Planque, B., and Fromentin, J.M. 1996. Calanus and environment in the eastern North Atlantic. I. Spatial and temporal patterns of C. finmarchicus and C. helgolandicus. Mar. Ecol. Prog. Ser. 134: 101-109.

Prinsenberg, S.J., Peterson, I.K., Narayanan, S., and Umoh, J.U. 1997. Interaction between atmosphere, ice cover, and ocean off Labrador and Newfoundland from 1962 to 1992. Can. J. Fish. Aquat. Sci. 54(Suppl. 1): 30-39.

Sameoto, D.D., Kennedy, M.K., and Petrie, B. 1996. SW Grand Banks, Scotian Shelf and Gulf of Maine zooplankton and phytoplankton measured by the continuous plankton recorder 1961 to 1993. Can. Tech. Rep. Fish. Aquat. Sci. 2116: $x i+219$ p.

Stein, M. 2000. Climatic conditions around Greenland - 1997. NAFO Sci. Counc. Stud. 32: 69-74.

Sy, A., Rhein, M., Lazier, J.R.N., Koltermann, K.P., Meincke, J., Putzka, A., and Bersch, M. 1997. Surprisingly rapid spreading of newly formed intermediate waters across the North Atlantic Ocean. Nature (London), 386: 675-679.

Warner, A.J., and Hays, G.C. 1994. Sampling by the Continuous Plankton Recorder survey. Prog. Oceanogr. 34: 237-256. 